\title{
The Cultivation and Preservation of the Martial Music of the Highlands by the Highland Society of London
}

\author{
JANICE FAIRNEY
}

In 1778, the Highland Society of London (HSL) was established to provide a more formal arrangement for Highland gentlemen based in London to come together at a dinner club. A safe haven, where they could enjoy the company of other Gaels and recall shared memories of their youth. But these London Gaels did far more than just remember or imagine the past. They became proactive in preserving a dying culture that was dear to them. It was the first society with a Gaelic cultural remit in either England or Scotland and its successes, which were many, must in some part, be accredited to its membership which consisted of the crème de la crème of those Highlanders who spent much of the year in London.

Their aim of preserving the ancient music of the Highlands was second only to the repeal of the Act proscribing Highland dress. ${ }^{1}$ They wished to preserve all the ancient music whether that of song, dance or war. However, it was the martial music 'adapted for the Great Highland Pipe' that received most of the HSL's attention.

Although the bagpipe was not specifically mentioned in the Disarming Act of 1746, the prosecution of John Reid, a Jacobite piper captured and executed in England, may have led to some fear on the part of pipers. ${ }^{2}$ However, the decline in playing the pipe was more probably due to the breakdown of traditional clanship and all its hereditary systems. With the loss of the hereditary piping schools, pipe music had effectively been silenced. Dr Samuel Johnson noted this fact in his account of his journey to the Highlands and Islands in 1773,

The solace which the bagpipe can give they have long enjoyed; but among other changes, which the last revolution introduced, the use of the bagpipe begins to be forgotten. ${ }^{3}$

Sir John Graham Dalyell wrote in his Musical Memoirs of Scotland that the bagpipe was regarded as 'a military instrument, and its special use to congregate vassals on their chief in warfare'. ${ }^{4}$ This purpose may well have added weight to the HSL's object of preservation, for many of its members had their own Highland Regiments, in fact Society members had raised

\footnotetext{
${ }^{1}$ The HSL led a successful campaign to achieve the repeal of the Disarming Act of 1746 in 1782.

${ }^{2}$ Scots Magazine 9 (746): 543.

${ }^{3}$ Johnson: 136.

${ }^{4}$ Dalyell: 88.
} 


\section{JANICE FAIRNEY}

all the Highland Regiments that had seen action during the American Civil War; these men would have certainly encouraged the martial aspect of piping.

The Society did, however, go further in its bid to preserve and cultivate the Great Highland Pipe; for it attempted to establish a piping academy to teach young men to become army pipers. It also encouraged the development of musical notation, to make learning the pipes both easier and quicker than by the old canntaireachd method of the hereditary piping schools. It is possible that Rev. Patrick Macdonald may have been the catalyst for action, when he sought the HSL's patronage during 1780. He wanted assistance in publishing his brother's collection of songs, and he was encouraged to enlarge the collection and to include some pipe tunes. This interest in pipe tunes may have led to the decision to hold a pipe competition.

However, we cannot state with certainty what reason was behind the Society's desire to preserve the music of the Great Highland Pipe; only that it wished to preserve the music and the best system of achieving this was initially through piping competitions.

\section{Piping Competitions}

According to Sir John Sinclair, it was simply a concern that the music of the Great Highland Pipe was 'fast hastening into oblivion'. Certainly, discussions took place regarding the fate of the Bagpipe, resulting in the proposal 'that a Pipe and flag be given annually by this Society to the best Performer on the Highland Bag-pipe, at the October Falkirk Tryste'. ${ }^{5}$ The motion was moved by the Earl of Eglinton on the 12 July 1781, and it was unanimously agreed upon.

The HSL quickly put its resolution into action, deciding that 'the Black Cattle Fairs held annually at Falkirk', considering the numerous Highlanders who were associated with them, would be 'the most suitable place for such a competition' ${ }^{6}$ It was also reckoned that the gentlemen qualified to judge such a competition would also be conducting business at Falkirk.

John Mackenzie, the society's Honorary Secretary, began organising the competition. Advertisments were placed in several Scottish newspapers through the assistance of $\mathrm{Mr}$ Elliot, a bookseller in Edinburgh, which stated:

A handsome Highland Pipe of the best construction is appointed to be given annually by the Highland Society of London to the best Player on that Instrument and also 40 merks in money-likewise 30 merks to be given to each of the two next best players-The competition to be annually at Falkirk Trytse in October. ${ }^{7}$

Mackenzie also ordered the Prize Pipe from Mr Hugh Robertson of Edinburgh, through the auspices of John Clark and his cousin Kenneth Mackenzie, Writer to the Signet. There are

\footnotetext{
${ }^{5}$ Sinclair: 13.

${ }^{6}$ NLS (National Library of Scotland), MS DEP 268/25: 100.

7 Mitchell Library (ML), TD.746/1 John Mackenzie's letter 20 September 1781.
} 


\section{THE CULTIVATION AND PRESERVATION OF THE MARTIAL MUSIC OF THE HIGHLANDS}

no extant minutes for this period, but from the actions of Mr Mackenzie, one can surmise that Mackenzie had also hoped that these two gentlemen would superintend the competition; he may very well have intended being there himself.

However, a fortuitous visit to Mackenzie by Rev. Dr Hugh Macleod, who had some business in London, changed the way in which the first and all subsequent competitions would be handled. For Macleod was a member of the HSL's first branch society, the Gaelic Society of Glasgow, better known as the Gaelic Club of Gentlemen. He accepted the invitation given by Mackenzie: that the Glasgow branch would readily undertake the honour bestowed by the Parent society and superintend the competition.

By this agreement the arduous task of running the actual competition was to be borne initially by the Glasgow branch from 1781, and then by the Highland Society of Edinburgh (HSE) ${ }^{8}$ until 1844, when the competition ceased.

Iain MacInnes' MLitt thesis (1989), Angus MacKay's Piobaireachd collection of 1838 and Sir John Graham Dalyell's book of 1849 all give accounts of these competitions, individual pipers and the tunes that were played. However, instead of discussing this aspect of the competitions, evidence will be provided which best reflects what the HSL wanted to achieve through these competitions.

Paramount in the minds of the members of the HSL was that the competitions would provide an avenue which would not only encourage piping, but also act as an impetus to improve the quality of the playing and preserve the ancient pipe music.

It is obvious from the records of the Highland Society of London, the Highland Society of Scotland and those of the Glasgow branch, that the Highland Society of London had overall control of all aspects of the competition. It provided the money for prizes, initially the prize pipes, and it carried all financial liability. The other societies, although bearing the brunt of the work in the actual running of the competition, followed the wishes of the Highland Society of London. This is illustrated in an early letter of the Glasgow Branch; it hoped that it would be 'a sufficient testimony of our zeal to second the laudable and patriotic views of your Society and to carry their [HSL] commands into Execution'. 9 This is illustrated further in the correspondence from the Highland Society of Scotland.

The Glasgow Branch ran the competition for three years. The first competition was a somewhat rushed affair, for Rev. Dr Macleod, having agreed that the Glasgow branch would accept the responsibility of the competition in September, did not return home to Glasgow until October, going via Edinburgh to pick up the Prize pipes. In reality the Glasgow branch had only eight days to organise the competition.

The Gaelic Club of Gentlemen was made up of the nouveaux riches of Glasgow, the merchants and industrialists, with the addition of clergymen and army officers; nearly all the

\footnotetext{
${ }^{8}$ The Highland Society became the Highland Society of Scotland (HSS) in 1808, and later changed its name to the Royal Highland and Agricultural Society of Scotland (RHASS).

${ }^{9}$ NLS, MS DEP 268/1, 29 October 1781.
} 


\section{JANICE FAIRNEY}

correspondence between it and the HSL was conducted through Rev. Dr Macleod, perhaps to add a touch of respectability to the club.

The first competition was a success due to a large extent to the enthusiasm of the Glasgow branch, the detailed instructions from the HSL, plus the assistance of Mackenzie's cousin acting as the HSL's representative. They ran the competitions from 1781-1783. At the beginning of all these competitions Duncan Ban Macintyre recited a poem composed especially for the occasion.

To ensure no bias on the part of the judges, the pipers performed unseen by the judges, and the order of playing was decided by a lottery; each piper pulled out a numbered ticket from a hat. The pipers had to perform a salute, a march or gathering, a lament and a piobaireachd. The judges had to first select the best six players. Those six performed again and then the three prize winners were selected. It was only then that the numbers on their tickets identified the prize winners. ${ }^{10}$ Highland dances were performed by some of the competitors to the enjoyment of those in attendance.

At this first competition the Gaelic Club of Gentlemen's committee and the selected Judges decided to take up a collection so that every competitor would receive something towards their expenses according to the merit of their playing.

Our deputation and their associates all agreed, that it would be cruel to dismiss the Ten unsuccessful candidates, without anything to bear their expence. ${ }^{11}$

This was done in the hope to encourage competitors to return the following year. Duncan Ban Macintyre also received a guinea for his appearance from the largesse of the committee.

The committee through the auspices of Rev. Dr Macleod made several recommendations to the HSL. Additional money should be made available so that all competitors could receive travel expenses as an inducement to compete; also that the winner of the Prize Pipes should not compete again, to avoid any discouragement among competitors who might give up, for it was better that they should be encouraged to improve their playing.

It also recommended that an inscription 'Duais [ ] na Piobreachd, O chomunn nan Gaidhel an Lunnuin', perhaps on a small piece of silver plate, with the date of the Competition, be placed on the box of the chanter. It believed that one should be added to Peter McGrigor's prize pipes, and this should be continued at every competition. It also suggested that the second and third placed pipers receive a chanter with an inscription on it, feeling that 'such a lasting monument [...] will have greater influence with Highlanders than three times the value in cash'. ${ }^{12}$ These recommendations were taken on board by the HSL, but a suggestion regarding the actual prize pipe was rejected. The committee superintending the competition were of the opinion that:

${ }^{10}$ ML, TD.746/1, Report of the Piping competition.

${ }^{11}$ ML, TD.746/1, Report of the Piping Competition.

${ }^{12}$ ML, TD.746/1, Minute Book copy of letter from Dr McLeod to John Mackenzie. 


\section{THE CULTIVATION AND PRESERVATION OF THE MARTIAL MUSIC OF THE HIGHLANDS}

The great octave Drone an article of considerable expence is unnecessary in a Highland Bagpipe, as it can seldom be filled by any man in motion; \& that it will be better to have only the Two unison drones and to apply the expence of the great Drone towards the Prize chanters above proposed. ${ }^{13}$

The first competition brought home the enormity of the fate of the music of the bagpipe; many pipe tunes were being forgotten. At the first competition the $3^{\text {rd }}$ prize-winner was John Macgregor, a 73 year old man, who when asked to play a march, announced that 'he had now forgot how to March or to play marches', but he would 'try to play the same he performed 35 years ago at the Battle of Falkirk'. ${ }^{14}$

At the second competition it was more apparent that some of the competitors could not all play the pieces selected by the judges, so substitution was allowed. ${ }^{15}$ There was a good size audience and a collection was taken to provide a bigger handout to the competitors. ${ }^{16} \mathrm{At}$ that competition the victorious competitors of 1781 and 1782, Peter Macgrigor and John McAlister, preceded the judges in a procession to the Falkirk Church, playing in unison the 'Lament of the Clans' marching around the monuments of Sir John Graham, Sir John Stuart and Sir Robert Munro. ${ }^{17}$ The Gaelic Club of Gentlemen had only one recommendation to the HSL, which was that an invitation should be made to gentlemen to send their pipers to the next competition.

The 1783 competition ended in uproar. It would appear that opening up the competition to gentlemen's pipers caused problems, most probably due to the noblemen themselves. Another antagonist to the Glasgow branch's efforts was a certain Mr David Trigge, who announced that he was the agent of the HSL and attempted to inform the judges how they were to run the competition. In a letter to the HSL, David Trigge reported that the competitors accused the judges of favouritism; this was echoed by some of the audience, and questions were raised about the suitability of 'arrogant Tradesmen' running the competition. ${ }^{18}$ Trigge also informed the HSL that some of the pipers in expressing their displeasure stated that they would not compete at another competition run by the Glasgow committee. Further, as a means of appeasing the pipers, Clanranald, a member of the HSL who was present at the competition, announced that Captain Clark of Loanhead, Sir George Clarke of Penicuik and John Clarke of Elden:

would redress the grievances of the Pipers and not only give their aid to encourage these Musicians but to promote the good intentions of the

\footnotetext{
${ }^{13}$ ML, TD.746/1, Copy of letter from Dr McLeod to John Mackenzie 30 October 1781.

${ }^{14}$ ML, TD.746/1, Copy of letter from Dr McLeod to John Mackenzie, 30 October 1781.

${ }^{15}$ NLS, MS DEP 268/14, 15 October 1782.

${ }^{16}$ The Scots Magazine, 1781 (43) 553 and Edinburgh Evening Courant, 29 October 1782.

${ }^{17}$ NLS, MS DEP 268/14, 15 October 1782.

${ }^{18}$ NLS, MS DEP 268/1, 29 October 1783.
} 


\section{JANICE FAIRNEY}

London Highland Society and ordered me [i.e. David Trigge, agent of the HSL] to invite the Competitors to Edinburgh where they should be treated in the most friendly manner and amply rewarded but nothing would do unless I would assure them that the Glasgow People were not to be there and the Seat of the Competition would in future be moved at length. ${ }^{19}$

An exhibition was held with great success attended by the nobility who were in Edinburgh at the time. Like the 1782 and 1783 competitions, the exhibition ended with all the pipers marching round St Andrew's Square playing 'Clanranald's March'.

The 1784 competition, originally planned for Falkirk, was moved at the last minute to Edinburgh by the HSE, under the direction of John Clarke of Elden. This competition was held in Dunn's Assembly Hall. However, all subsequent competitions were held in the Theatre Royal. It followed the same formula as the exhibition of the previous year, consisting of three acts in which the pipers performed piobaireachd interspersed by Highland dances. Duncan Ban Macintyre opened the competition with his annual Gaelic poem praising the bagpipe. It should be noted that the judges of the HSE held run-offs for a place in the actual competition, and this set the precedent for future competitions. In 1809, the HSL increased the number of prizes to five in each category as a means to encourage participation.

The HSL was desirous that the number and names of tunes known by the competitors should be collected and that musical notation should be encouraged. These desires are illustrated by the alteration of regulations for competitions. From 1805, premiums were awarded to pipers who showed the judges examples of musical scores, as a way of preserving piobaireachd. Prizes were awarded to Donald MacDonald in 1806, his son John in 1808, and to Angus Mackay in 1825, in fact 'a total of sixteen awards were made to nine individuals' ${ }^{20}$ However, in 1829 the HSS committee decided unilaterally to shorten the advertisement for the competition and to leave out that 'part which relates to the notation of Pipe Music'. ${ }^{21}$

In 1823, the HSL informed the HSS that each piper was to submit to the judges a list of at least twelve pieces of piobaireachd. The judges would then call upon each piper to perform one of the pieces from his list. There must have been some concern regarding the actions and perhaps the suitability of some of the judges appointed by the HSS, for the HSL stated that: 'in performing any piobaireachd, each Piper is to be left entirely to himself, and is not to be directed to play short'. It also ruled that dissatisfied competitors could never compete again. ${ }^{22}$

Although the competitions were well attended, the audiences began to fall away in the 1820s, due in part to the increase in the provincial Highland Gatherings. The 1826 piping competition ran at a loss and the HSS recommended that the competition should be held once every three years.

\footnotetext{
${ }^{19}$ NLS, MS DEP 268/1, 29 October 1783.

${ }^{20}$ MacInnes 1989: 215.

${ }^{21}$ RHSS, PMB: 64.

${ }^{22}$ RHSS, PMB: 10.
} 


\section{THE CULTIVATION AND PRESERVATION OF THE MARTIAL MUSIC OF THE HIGHLANDS}

For the first Triennial Competition in 1829 the HSL recommended the following to be adopted by the HSS:

In order to prevent pipers not properly qualified from appearing at this great triennial competition, and at the same time with a view of encouraging the competitions at the Provincial or District Highland Societies, and generally to promote the acquirement of perfection in Pipe Music, the Competitors for the Prizes of this Society be in future limited to those Pipers who shall have already obtained Prizes at some of the local meetings, of which they shall be required to produce Certificates from the President or Secretary of the Provincial Highland Societies by whom the Prizes may have been awarded. Regimental Pipers producing a proper Certificate of qualification from their Commanding Officer, or any pipers resident in a District where no local Highland Society is established, producing testimonials from three neighbouring Highland Gentlemen of their being properly qualified to compete for the Prizes of this Society. ${ }^{23}$

In the run-up to the 1835 competition, the HSS recommended that some of the 'ancient pipers' should appear at the competition. However, the HSL felt that it would be more appropriate to hold a competition for all the previous winners of the prize pipes with a Gold Medal presented to the Champion.

The HSS made numerous suggestions to the HSL regarding the inclusion of reels and strathspeys on both the pipe and the violin at the competition from 1835 until 1844. However, the HSL was not interested in this; as Dalyell, one of the HSS committee, said 'The Highland Society of London did not listen to these proposals [...] they replied that one named McKerracher from Pitrothis [sic] and another Duff at Aberdeen were the best players of reels'. ${ }^{24}$ The HSL refused to be drawn away from its goal of preserving piobaireachd and believed that the Provincial Games were a better venue for reels and strathspeys. The last competition run by the HSS for the HSL took place in 1844. The HSS decided it no longer wanted to supervise the competition and suggested that the Celtic Society of Edinburgh might be willing to take its place. ${ }^{25}$

However, the HSL decided to support the Northern Meeting at Inverness as a means of maintaining its initial objective. Several members of the HSL were involved with the Northern Meeting, an agricultural show that introduced a dance and pipe competition from 1839. According to Angus Fairrie:

\footnotetext{
23 RHASS, PMB: 61.

${ }^{24}$ EUL (Edingurgh University Library), Gen.369D: 42

${ }^{25}$ RHASS, Sederunt Book, Vol.20: 531
} 


\section{JANICE FAIRNEY}

There seems to have been no formal exchange of credentials. It was simply assumed by the Highland Society that the setting for its historic competition had been transferred from Edinburgh to Inverness. Meanwhile the Northern Meeting, being at this time eager to reinforce the success of its newly established public Games, was happy to accept the addition of the Piping, almost certainly without realising the significance of the move. ${ }^{26}$

The Northern Meeting did have a competition for the popular Marches and Strathspeys but it was only the piobaireachd competition that the HSL was involved with. It gave a gold medal for the 1849 competition; it was not until 1859 that the HSL decided to give an annual award of the 'Champion Gold Medal' for previous winners of the Prize Pipes. In 1887 the award of Prize Pipes at the Northern Meeting was discontinued, replaced by the HSL's Gold Medal for Piobaireachd as the highest award for the competition. In 1875, the HSL also began to give the same award to the Argyllshire Gathering in Oban. These Gold Medals are still regarded as the pinnacle of piping achievement.

\section{The piping academy}

As noted earlier the HSL was interested in the establishment of a piping academy as a way of cultivation and preservation. It is doubtful, that the HSL, considered the possibility of a piping college to train pipers for the army, prior to its competitions. However, at the exhibition in Edinburgh a few days after the Falkirk competition of 1783, Clanranald, a member of the HSL and President of the exhibition, presented John MacArthur, also known as Professor MacArthur, with a set of bagpipes. With the bagpipes was a signed declaration from all involved with the exhibition, the committee of management and the other competitors, as an encouragement 'to establish a college for the instruction of such young men as may be sent to be bred to that ancient music, the utility of which in recruiting his Majesty's army, and the military ardour with which it inspires highland regiments, are too well known to say anything further'. ${ }^{27}$ MacInnes is doubtful whether MacArthur did indeed start a school and if he did, it did not flourish (MacInnes 1989: 118). At all events, five years later the idea of a piping college arose again.

It should be noted that Lieutenant Donald Ruadh MacCrimmon, who would later be selected as the Professor, joined the HSL in March 1788. His membership may have acted as a catalyst in the society's promotion of a Piping Academy. He was a member of the MacCrimmon hereditary piping family and had received much of his early training from Patrick $O g .{ }^{28}$

It is very possible that conversations regarding the piping seminary run by the MacCrimmon family provided the impetus for Murchison's report regarding the need of a

\footnotetext{
${ }^{26}$ Fairrie 1988: 42.

${ }^{27}$ Edinburgh Evening Courant, 27 October 1783.

${ }^{28}$ The Macrimmons were hereditary pipers to Macleod of Dunvegan, who had run a piping seminary for many centuries. Patrick Og was reputedly the last composer of note from that family.
} 


\section{THE CULTIVATION AND PRESERVATION OF THE MARTIAL MUSIC OF THE HIGHLANDS}

piping academy. In July 1789, 'Mr Murchison produced and read a plan for Establishing a Professor of the Great Highland Pipe'. ${ }^{29}$ His suggestion met with support from the members and he was empowered to correspond with Mr Grant of Corrymonie, 'or such Gentlemen in Scotland, as he may judge proper for the purpose of obtaining all possible information, together with Estimates and Statements of the real expence that may be necessary for the completion of this undertaking'. ${ }^{30}$

MacCrimmon had moved to London to find suitable employment, but his fortunes continued to spiral downwards. He had lost his home and lands during the American War of Independence and while in London he became financially destitute and ended up in Newgate Prison for debt. He petitioned the HSL through the auspices of Allan Cameron of Erracht in April 1789. Several members of the society supported the petition and the HSL gave MacCrimmon twenty guineas from its funds. ${ }^{31}$ It also provided passage home to Scotland for MacCrimmon, his wife and three children.

Mr Kenneth Murchison gave a further report to the HSL, and after discussion it was decided that the most expedient way to raise money for 'preserving the Ancient purity of the Music of the Highland Bagpipe' was to open a general subscription. ${ }^{32}$ It is obvious from subsequent minutes that a General Court meeting of 20 May 1789 had decided that MacCrimmon would became the Professor of the Piping Academy. It detailed what was expected of him in that role and what he was to report back annually to the Society. ${ }^{33}$ Although the General Court Minute Book is no longer extant, the minute of 4 June 1790 reported on that resolution of the General Court.

MacCrimmon was nominated to be Professor of the Great Highland Bagpipe, at the Barracks in Glenelg, by Col. Macleod of Macleod. The society gave MacCrimmon his salary for one year in advance with an additional thirty pounds for relocation expenses, but the thirty pounds would be paid in instalments, the last to be paid out during March 1791. ${ }^{34}$ Although this was done, the HSL was not so successful in securing the use of Glenelg Barracks for MacCrimmon and his students. Col. Macleod presented the first petition to Lord Adam Gordon, a fellow HSL member who was the Commander in Chief in Scotland. The Marquis of Huntly made a second appeal. By the end of December, the HSL was informed that the Glenelg Barracks could not be used for a piping academy. So Col. Small was requested to make Col. Macleod of Macleod aware: 'of the great disappointment the Committee feel on this occasion as it may prove fatal to the favourite object of the Society in preserving and promoting the Gaelic music' and to ask for Macleod's assistance. ${ }^{35}$

\footnotetext{
${ }^{29}$ NLS, MS DEP 268/21: 91.

${ }^{30}$ NLS, MS DEP 268/21: 91.

${ }^{31}$ NLS, MS DEP 268/21: 96-7.

${ }^{32}$ NLS, MS DEP 268/21: 99.

${ }^{33}$ NLS, MS DEP 268/21: 148.

${ }^{34}$ NLS, MS DEP 268/21: 115.

${ }^{35}$ NLS, MS DEP 268/21: 126.
} 


\section{JANICE FAIRNEY}

In response, Macleod provided a farm on his estate for Mr MacCrimmon. It was then made clear that the HSL had informed MacCrimmon on how he was to instruct his pupils in the (now lost) minute of May 20, 1790. ${ }^{36}$ MacCrimmon was reminded of all his commitments to the HSL. However, the June minute notes that he had not complied, and a letter was written to MacCrimmon:

informing him that as the object of the Society, has totally failed, the salary to Mr Maccremmon [sic], is to be discontinued but declaring, that if he will fix himself, in any situation in Glenelg or near Fort Augustus, and carry the Society's original intentions into execution, his Salary will be continued provided he reports his having made progress towards that settlement, on or before the first day of November next. ${ }^{37}$

A letter was received from MacCrimmon's daughter Marion Mackinnon dated 11 December 1793, stating that her father was 'now ready to instruct pupils as proposed by the Society'. A letter was sent to her informing her that the Society 'will receive no communication regarding the piping academy except from MacCrimmon himself' ${ }^{38}$

The HSL's plan had not worked and the real cause for failure is unknown, but one must assume that the fault did not lie with MacCrimmon alone, for in 1808, after eighteen months of living in London, he again petitioned the HSL. ${ }^{39}$ Once more the HSL came to his aid and sent a deputation to His Royal Highness the Duke of York and Albany, who was now the Commander in Chief, asking for a promotion for MacCrimmon, and also informed him:

That notwithstanding the success with which the efforts of the Society have been attended for the preservation and cultivation of Pipe Music for the Highland Corps in the Army, their endeavour may ultimately prove ineffectual without establishment of a National Academy in the Highlands of Scotland, where students shall be instructed in every branch of Pipe Music. And that the said Deputation do express to His Royal Highness the earnest wish of the Society that His Royal Highness would be pleased to promote Lieutenant Donald MacCrimmon of the $10^{\text {th }}$ Veteran Battalion to permanent Rank in the Garrison of Fort William or Fort Augustus with such provision for the support of the Establishment. ${ }^{40}$

The HSL advanced MacCrimmon as the only suitably qualified candidate, the last of the hereditary family who for five centuries had presided over a similar institution, and emphasised the necessity of doing something before he died, when a whole corpus of pipe music known only by him would be lost forever. The deputation consisted of the Marquis of

\footnotetext{
${ }^{36}$ NLS, MS DEP 268/21: 147.

${ }^{37}$ NLS, MS DEP 268/21: 152

${ }^{38}$ NLS, MS DEP 268/22: 15

${ }^{39}$ NLS, MS DEP 268/1, petition, 8 August 1808

${ }^{40}$ NLS, MS DEP 268/25: 4-5
} 


\section{THE CULTIVATION AND PRESERVATION OF THE MARTIAL MUSIC OF THE HIGHLANDS}

Huntly, Maj. Gen. T.R. Mackenzie, Lieut. Col. The Hon. Godfrey Macdonald, Sir John Sinclair, Sir John Macpherson and Sir John Macgregor Murray. The Duke of York intimated that he was in favour, but had more pressing matters that needed attention before he could consider the Society's proposal. ${ }^{41}$

MacCrimmon was at that time on Leave of Absence from his regiment. That leave was quickly running out and he would soon have to embark for Nova Scotia. The HSL wrote to its President, the Duke of Sussex, outlining its position in that letter, stating that it wanted MacCrimmon to be given a Captain's Commission, and that if the barracks were not being used, what better purpose could they be put to 'than to be a Repository for the Cultivation of a branch of Music which is known to animate and preserve the Military spirit of the Highlanders'. ${ }^{42}$ It further suggested that as a means of making the proposal successful, the different regiments could by enlistment select suitable candidates for students of the pipe. The Duke of Sussex expressed his compliance with the request to approach his brother, the Duke of York, and to request that MacCrimmon's Leave of Absence should be extended until he could consider the HSL's proposal.

Another period of five years elapsed before the Academy for Pipe Music was raised again. MacInnes reported that MacCrimmon had not been sent to Canada but was stationed at Fort George, and that the Duke of Kent expressed an interest in having MacCrimmon as pipe instructor for his own Regiment. ${ }^{43}$ That was in 1813. However, by 1816, Col. Macdonnel of Glengarry was agitating for the Piping Academy to succeed. He had been a member of the HSL for many years, but it was in his role as founder and President of the Society of True Highlanders that he addressed the society. He asked for extracts of the minutes regarding the Piping College at Fort William or Fort Augustus and the reasons for its failure. He hoped that his society might be able to further the HSL plans. ${ }^{44}$ The HSL complied with his request, but informed him that it would soon be in a financial situation to continue its plan for an Academy for Pipe Music. It was indicated in the correspondence between the HSL and Macdonnel that the HSL was considering Angus McArthur, ${ }^{45}$ who was brought to London by Lord Macdonald, and was related to a past HSL piper, Charles MacArthur. However, Macdonnel disagreed, arguing that:

The person best qualified by much to fill the situation with respectability and efficacy, unless he has committed some unpardonable offence is Lieutenant McCrummon [sic], noticed so properly in the extracts with which you have just favoured me [...] but from the estimation in which Mr McArthur stands, and considering

\footnotetext{
${ }^{41}$ NLS, MS DEP 268/25: 18

${ }^{42}$ NLS, MS DEP 268/25: 24-26.

${ }^{43}$ NLS, MS 19553, fol. 9, quoted in MacInnes: 121-2.

${ }^{44}$ NLS, MS DEP 268/26: 131.

${ }^{45}$ NLS, MS DEP 268/26: 162.
} 


\section{JANICE FAIRNEY}

McCrumons [sic] time of life, if he come forward as assistant [...] I have not the smallest doubt but that he would be well qualified to fill the vacancy Lieutenant McCrummon must in course of nature give room for another. ${ }^{46}$

The final mention of the Piping Academy was on 5 April 1816 with the usual resolutions regarding the need for one and the suitability of MacCrimmon 'from his high reputation as a Performer, and being one of the few remaining Descendants of the Real MacCrimmon Race the ancient and renowned Professors of the National Instrument' ${ }^{47}$ A vacancy was expected at Fort William in the near future and it was decided to solicit the Lords of the Treasury to appoint MacCrimmon to the vacancy and to allow him to teach students on the pipes. Whether the HSL realised it was flogging a dead horse, or whether more important issues such as the society's incorporation took precedence, the Academy for Piping became a dead issue.

\section{Musical Notation}

The HSL, as already noted, was very interested in proper musical notation for pipe music, as a means to both preserve the music and to assist teaching the instrument. The first attempt at achieving this was through the patronage of Patrick McDonald's songbook ${ }^{48}$. The second was Joseph Macdonald's Compleat Theory of the Scots Highland Bagpipe, which John Macgregor Murray found in Bengal in 1784. Murray sent it to the HSL, and it was reported at the 28 April 1785 meeting that 'the plan of publication of the Treatise on the Highland Pipe, now under consideration to Mr George Mackenzie and Mr James Morison to report their opinion to the committee'. ${ }^{49}$ However, there is no further mention of it, and in 1803 Patrick Macdonald himself published the book by subscription and dedicated it to Sir John Macgregor Murray. In 1804, at the suggestion of Sir John Sinclair, copies of the book were given to those competitors at the Competition of Pipers who had made the greatest improvement. ${ }^{50}$ It might also have been given as an encouragement for more pipers to employ musical notation. From 1805 the advertisement for the pipe competition stated that premiums would be given for pipe music on the stave. This was reinforced in 1815, when John Macgregor Murray suggested that premiums should be given to pipers who brought in written pipe music and 'playing from the Book, to facilitate the instruction of performers, and as a means of fixing and improving the music of the national instrument'. 51 Another early work also dedicated to Sir John Macgregor Murray was A. Menzies' The Bagpipe Preceptor (1818). In it Menzies says: 'when you are master of the instrument I shall recommend you to attend the competition of pipers in Edinburgh [...] and who knows but you may one of these

\footnotetext{
${ }^{46}$ NLS, MS DEP 268/26: 143-4.

${ }^{47}$ NLS, MS DEP 268/26: 200.

48 McDonald 1784.

${ }^{49}$ NLS, MS DEP 268/21: 43.

${ }^{50}$ Mackay 1838: 17.

51 NLS, MS DEP 268/26: 112.
} 


\section{THE CULTIVATION AND PRESERVATION OF THE MARTIAL MUSIC OF THE HIGHLANDS}

days "scorn the shepherd's slothful life" and launch into the service of your King and Country in the capacity of a piper'. ${ }^{52}$

In 1819, Mr Andrew Robertson addressed the HSL committee stating that:

One of the principal objects of the Society being the preservation of the ancient Music of Scotland it was desirable that some attention should be paid to a Plan lately adopted for simplifying the process of learning and teaching Bagpipe Music, it was generally understood that the Piobrachds [sic] could be communicated to Paper with the same facility as the music of the Violin and Piano, and it was the utmost importance that these valuable pieces of ancient Music should be forthwith put down so as to be rendered legible to every Musician. ${ }^{53}$

Robertson proposed John MacGregor, the society's piper, for such a task, but the society decided that MacGregor would be employed to 'write and arrange for Bagpipe playing from the information and subject to the approbation of Angus McArthur'. MacGregor was to be paid one guinea for each of the requested twenty-four pieces of music. $^{54}$

However, a further twenty-six 'well selected additional Piobrachs [were to] be taken down by John McGregor from the recitation of Angus McArthur upon the same terms and in the same manner as those formerly ordered'. ${ }^{55}$ The manuscript was written during July and August 1820 from 'the whistling of Angus McArthur'. ${ }^{56}$ MacInnes believes that McArthur actually used a practice chanter for this. ${ }^{57}$ Nearly four years later, the Secretary, John Wedderburn suggested that John Gow ${ }^{58}$ should inspect and give an estimate of the cost of publishing the manuscript. ${ }^{59}$ Gow's estimate for forty-three pounds and eighteen shillings was duly received and a committee appointed to see the manuscript through publication. ${ }^{60}$ It obviously decided to expand the production, and wrote to the HSS for tunes left with the judges of the competition. Charles Gordon, the deputy secretary, on forwarding the sheets of music, acknowledged they were the property of the HSL; he stated further that:

The very few Pipers who were qualified to note the piobrachd, had generally but one copy of the Tunes committed to writing, and which

\footnotetext{
${ }^{52}$ A Menzies, The Bagpipe Perceptor (Edinburgh, 1818), p. 34, quoted in MacInnes 1989::124-5.

${ }^{53}$ NLS, MS DEP 268/43: 2.

${ }^{54}$ NLS, MS DEP 268/43: 6.

${ }^{55}$ NLS, MS DEP 268/43: 9.

${ }^{56}$ NLS, MS DEP 268/17, 1 July 1820.

${ }^{57}$ MacInnes 1989: 223.

${ }^{58}$ John Gow was the second son of Neil Gow. He performed with his band at HSL meetings until his death in 1827. He also operated a publishing business in London.

${ }^{59}$ NLS, MS DEP 268/27, 6 Mar 1824.

${ }^{60}$ NLS, MS DEP 268/27, 1 May 1824.
} 


\section{JANICE FAIRNEY}

copy they declined to leave with the Committee altho' they promised to produce a transcript at some time after the Comp and were promised a reward upon their doing it, in nearly every instance the promises of the Piper were made only to be forgotten. ${ }^{61}$

He also noted that until recently only Military Pipers could make use of notation, and most still learnt the tunes in the old way by ear. He stated that the publication in view 'will also do much to music and fix the paper standard for each tune for at present scarcely two pipers play exactly the same set of any piobrachd'. He also reminded the HSL of Angus Mackay's very large collection of Pipe Music, which the judges had seen at the last competition. ${ }^{62}$ The HSL committee was also requested to assess Mr Macrae's collection of piobaireachd. ${ }^{63}$ The committee's report was read and accepted on the 4 February $1826 .{ }^{64}$ However, Angus McArthur's collection was never published. In November 1833, Robert Edmonstone, a member of the HSL, requested the manuscript for two or three months, explaining that some Highland Pipers were anxious to get their own collection published and wanted access to the manuscript which 'altho' not on the scale of the Pipes they may be of use'. ${ }^{65}$ The manuscript was sent, and one of the pipers requesting access to it was probably Michael Macfarlane, for it was his widow who sold it to Charles Bannatyne. The Pìobaireachd Society purchased it on his death and deposited it with the NLS. ${ }^{66}$

The HSL patronised Captain Macleod of Gesto's collection at the recommendation of the HSS. It was called A Collection of Piobaireachds or Pipe Tunes as verbally taught by the McCrummen Pipers in the Isle of Skye to their Apprentices now published, as taken from John McCrummen, piper to the old Laird of Macleod and his Grandson the late General Macleod of Macleod. ${ }^{67}$ However, it was not what the society had expected, for it would appear that none of its members had seen canntaireachd before; this was illustrated by the correspondence between the HSS and HSL. The HSL wanted to know if the HSS had given Macleod any encouragement and how far 'the work may be considered as a means of cultivating the knowledge of Pipe Music or of enabling a Piper without a previous acquaintance with the Tunes to play the piobaireachd'. ${ }^{68}$ The HSS responded 'that it was a curiosity in its way' ${ }^{69}$ and that the HSS 'have always abstained from any direct patronage of the Bagpipe or its music which have been so long and so successfully patronised by the

\footnotetext{
${ }^{61}$ NLS, MS DEP 268/2, 16 Nov 1825.

62 NLS, MS DEP 268/2, 16 Nov 1825.

${ }^{63}$ NLS, MS DEP 268/27 5 Mar 1825.

${ }^{64}$ NLS, MS DEP 268/27 4 Feb 1826.

${ }^{65}$ NLS, MS DEP 268/4, 18 November 1833.

${ }^{66} \mathrm{NLS}$, MS 1679, the manuscript has been published in a new edition published by Glasgow and Aberdeen University in 2001, Frans Buisman \& Roderick D Cannon, eds., The Music of Scotland: Volume I: The MacArthur-MacGregor Manuscript of Piobaireachd (1820).

${ }^{67}$ MacLeod 1828.

${ }^{68}$ NLS, MS DEP 268/27 7 February 1829.

${ }^{69}$ NLS, MS DEP 268/3 26 July 1828.
} 


\section{THE CULTIVATION AND PRESERVATION OF THE MARTIAL MUSIC OF THE HIGHLANDS}

Highland Society of London' ${ }^{70}$ Eventually the HSL paid the ten guineas promised to Captain Macleod. ${ }^{71} \mathrm{He}$ dedicated his collection to the HSL.

The collection of piobaireachd that the HSL eventually sponsored, and which greatly influenced and helped to standardise pipe music, was that of Angus Mackay, published in 1838. He was the HSL's piper, as well as being piper to Queen Victoria, the GSL (Gaelic Society of London) and the London Club of True Highlanders. The work was begun in 1835, but it had taken him longer to compile than he had anticipated. He dedicated it to the HSL, stating in his preface that:

It is with feeling of pride that he now dedicates his labours to the Highland Society of London, whose patriotic encouragement of Gaëlic manners and customs is so well known, and whose patronage, so generously bestowed on his work, confers so much honour, and is so gratifying to the Editor. ${ }^{72}$

MacInnes believed that James Logan was involved with Mackay's publication and cites as evidence a letter written by Logan to the Secretary of the HSL. In that letter he makes reference to copies of Mackay's piobaireachd still in his possession. ${ }^{73}$ MacInnes states that he is not sure of the extent of the HSL involvement but feels that it might have been involved with the editing. ${ }^{74} \mathrm{He}$ was indeed correct in that assumption, as demonstrated by James Logan in a letter to the editor of the London Scotsman responding to an article he had read concerning a new 'Collection of Pipe Music' by William Ross, who was at that time piper to the Queen, the HSL and also the GSL. Logan corrects the erroneous statement given in the paper that Ross's was the first published collection, stating that Mackay had published a collection of sixty-one genuine old piobaireachdan, with curious traditional and historical accounts of the composers, the occasions on which they were composed, anecdotes, and other appropriate memoranda, 'which I had the pleasure of arranging for the press'. ${ }^{75}$

\section{Conclusion}

The HSL is probably best known for its aim of preserving the martial music of the Highlands played on the Great Highland Pipe. It organised the first ever pipe competition in 1781 at Falkirk, and continued to hold the competition with the assistance of its Glasgow branch and the HSS until 1844. The competitions were soon enlarged to include dress and dance. These competitions were the genesis of the district Highland games run by members of the HSL, which eventually developed into the worldwide phenomenon of Highland Games that we

\footnotetext{
${ }^{70}$ NLS, MS DEP 268/3 28 April 1829.

${ }^{71}$ NLS, MS DEP 268/14, 2 May 1829.

72 MacKay 1838: 5.

${ }^{73}$ NLS, MS DEP 268/5, 24 April 1840.

${ }^{74}$ MacInnes 1989: 253.

${ }^{75}$ London Scotsman, 13 August 1870: 106.
} 


\section{JANICE FAIRNEY}

know today. With the end of the piping competitions it went on to award the HSL Gold Medal at the Northern Meeting and the Argyllshire Gathering. This prestigious award is still the most coveted prize for piobaireachd in the world. The Society's only real failure was not establishing a Piping Academy to train young men as Army pipers. It had more success in standardising pipe tunes by the encouragement of the use of staff notation, a process begun in 1784. This had a dual purpose, of preserving the piobaireachd before they were lost, and of simplifying bagpipe instruction, as a way of addressing the shortage of army pipers. This process led to the standardisation of piobaireachd as we are now accustomed to hear it.

Without the foresight of those first members of the HSL, and the continued determination of its members through the years, Dr Samuel Johnson's diagnosis that 'the bagpipe begins to be forgotten' might have become a reality.

\section{REFERENCES}

BUISMAN FRANS AND RODERICK D. CANNON, EDS.

2001 The Music of Scotland: Volume I: The MacArthur-MacGregor Manuscript of Piobaireachd (1820). Glasgow and Aberdeen.

DALYELL, SIR JOHN GRAHAM.

$1849 \quad$ Musical Memoirs of Scotland. Edinburgh.

DALYELL

Day Books. Gen.369D.

EDINBURGH EVENING COURANT.

FAIRRIE, ANGUS.

$1988 \quad$ The Northern Meeting 1788-1988. Edinburgh: Pentland Press

GAELIC SOCIETY OF GLASGOW (GAELIC CLUB OF GENTLEMEN).

Minute Book 1780-1867. TD.746/1

HIGHLAND SOCIETY OF LONDON.

Correspondence 1781-1820. MS DEP 268/1.

Correspondence 1820-1827. MS DEP 268/2.

Correspondence 1828-1831. MS DEP 268/3.

Correspondence 1831-1838. MS DEP 268/4.

Correspondence 1838-1841. MS DEP 268/5.

Draft Minutes 1820-1840. MS DEP 268/14.

Accounts and Receipts 1817-1829. MS DEP 268/17.

Minute Book 8 February-17 December 1793. MS DEP 268/21

Committee Minute Book 1793-1802. MS DEP 268/22.

Minute Book 1808-1814. MS DEP 268/25. 
Minute Book 1814-1816. MS DEP 268/26.

Minute Book 1822-1829. MS DEP 268/27.

Extracts of the Proceedings of the Society from 1819-1824. MS DEP $268 / 43$.

JOHNSON, SAMUEL.

1822 A Journey to the Western Islands of Scotland in 1773. London.

McDONALD, PATRICK.

$1784 \quad$ Highland Vocal Airs. Edinburgh

MACINNES, IAIN.

1989 The Highland Bagpipe: the impact of the Highland Societies of London and Scotland'. Unpublished MLitt thesis, University of Edinburgh.

MACKAY, ANGUS.

$1838 \quad$ Collection of Ancient Piobaireachd or Highland Pipe Music. 1972 ed. Wakefield.

MACLEOD, NEIL (GESTO)

1828 A collection of piobaireachd or pipe tunes: as verbally taught by the M'Crummen pipers in the Isle of Skye to their apprentices.

ROYAL HIGHLAND AND AGRICULTURAL SOCIETY OF SCOTLAND.

Provisional Minute Book.

ROYAL HIGHLAND AND AGRICULTURAL SOCIETY OF SCOTLAND.

Sederunt Book Vol. 20.

SINCLAIR, SIR JOHN OF ULBSTER.

1813 An Account of the Highland Society of London. London.

THE LONDON SCOTSMAN.

THE SCOTS MAGAZINE. 